\title{
Corrosion behavior in Ringer solution of several commercially used metal alloys
}

\author{
Carmen Marina Garcia-Falcon \\ Department of Mechanical Engineering, University of Las Palmas de Gran Canaria, Las Palmas de Gran Canaria, Spain \\ Tomas Gil-Lopez and Amparo Verdu-Vazquez \\ Department of Building Technology, Madrid Polytechnic University, Madrid, Spain, and \\ Fulia Claudia Mirza-Rosca \\ Department of Mechanical Engineering, University of Las Palmas de Gran Canaria, Las Palmas de Gran Canaria, Spain
}

\begin{abstract}
Purpose - This paper aims to analyze the corrosion behavior in Ringer solution of six commercially used Ni-based alloys that are present and commonly used as metallic biomaterials.

Design/methodology/approach - The specimens were received in the form of cylindrical ingots and were cut to get five samples of each brand with a cylindrical shape of $2 \mathrm{~mm}$ height to conduct the study. In this scientific research, the following techniques were used: open circuit potential, potentiodynamic polarization studies, and electrochemical impedance spectroscopy.

Findings - The study findings revealed the passivation tendency of the different specimens. Additionally, when the materials were compared, it was discovered that the decisive factor for high corrosion resistance was the chromium concentration. However, with similar chromium content, the stronger concentration in molybdenum increased the resistance. According to the results obtained in this investigation, the biological safety of the dental materials studied in Ringer solution was considered very high for specimens 1 and 2, and adequate for the other samples.

Originality/value - Metal alloys used as biomaterials in contact with the human body should be deeply investigated to make sure they are biocompatible and do not cause any harm. The corrosion resistance of an alloy is the most important characteristic for its biological safety, as all problems arise because of the corrosion process. There is scarce investigation in these Ni-based dental biomaterials, and none found in these commercially used dental materials in Ringer solution.
\end{abstract}

Keywords Nickel-based alloys, Metallic biomaterials, Corrosion, Passivity, Dental materials, Ringer solution

Paper type Research paper

\section{Introduction}

There are many possible alloys for prosthetic restorations (Lee et al., 2006; Mareci et al., 2008; Mareci et al., 2010; Souza et al., 2019), and among them Ni-based alloys are typically used in porcelain fused to metal (PFM) and casting crowns and bridges. This is due to the easy manufacturing procedure, availability, low price and last but certainly not least, corrosion resistance of these metallic biomaterials. Nickel-based alloys containing chromium develop a thin protective oxide layer on their surfaces, although they show unstable galvanic corrosion (Gushcha et al., 2019; Taher and Al Jabab, 2003). Certainly, the body environment is complex and presents difficult challenges regarding corrosion control that may be experienced by metallic biomaterials (Eliaz, 2019). The resistance to corrosion of an alloy is the most important characteristic for its biological safety, as all problems (local toxicity, allergies, etc.) arise from the elements released into the mouth because of the corrosion process (Rupp et al., 2018). Electrochemical studies

The current issue and full text archive of this journal is available on Emerald Insight at: https://www.emerald.com/insight/0003-5599.htm

Anti-Corrosion Methods and Materials

68/4 (2021) 324-330

(C) Emerald Publishing Limited [ISSN 0003-5599]

[DOI 10.1108/ACMM-05-2021-2486] for a limited number of Ni-Cr dental materials in artificial saliva medium were conducted by our group (Mareci et al., 2007; Mareci et al., 2008; Mareci et al., 2010), and we are now investigating in simulated body fluid (Ringer solution). We have recently presented the study of Co-Cr dental materials in Ringer solution (Garcia-Falcon et al., 2021).

Nickel was found to be highly toxic with epithelial cells and fibroblasts (Hornez et al., 2002). However, contradictory results were reported (Alp et al., 2018; Craig and Hanks, 1988; Craig and Hanks, 1990; McGinley et al., 2013; López-Alías et al., 2006). Additionally, to improve clinical characteristics,

\begin{abstract}
Author contributions: conceptualization, C.M. Garcia-Falcon; writing original draft, C.M. Garcia-Falcon; methodology, C.M. Garcia-Falcon and T. Gil-Lopez; investigation, C.M. Garcia-Falcon and T. Gil-Lopez; validation, T. Gil-Lopez; formal analysis, C.M. Garcia-Falcon and T. GilLopez; data curation, T. Gil-Lopez and A. Verdu-Vazquez; writing review and editing, A. Verdu-Vazquez; software, J.C. Mirza-Rosca; and supervision, J.C. Mirza-Rosca. All authors have read and agreed to the published version of the manuscript. Please turn to the CRediT taxonomy for the term explanation. Authorship must be limited to those who have contributed substantially to the work reported.
\end{abstract}

Funding: This research received no external funding.

Conflicts of interest: The authors declare no conflict of interest.

Received 1 June 2021

Revised 25 June 2021

Accepted 25 June 2021 
manufacturers produced by casting or SLM (Selective Laser Melting) Ni-Cr alloys with an increased percentage of nickel (Honga et al., 2019).

Although nickel allergies are common, it is clear that the use of Ni-Cr alloys in the oral cavity does not always cause an allergic reaction. Nickel is an essential element, with approximately $10 \mathrm{mg}$ contained in the human body, and adults consume between 79 and 105 micrograms of nickel per day from dietary sources and supplements (Insel et al., 2018). The methods used in measuring and predicting how the body responds to dental alloys remain to some extent unsuccessful, as well as confusing and controversial. However, what is clear is that allergies to alloys cannot occur if there is no corrosion and the corresponding release of metal ions.

$\mathrm{Ni}-\mathrm{Cr}$ dental alloys are available and commonly used. This investigation evaluated and compared six commercially used nickel-chromium dental materials manufactured in Germany, Romania and the USA. Their corrosion behavior in Ringer solution was analyzed using various techniques: open circuit potential (OCP), potentiodynamic polarization studies and electrochemical impedance spectroscopy (EIS). In service conditions, these metal alloys are in contact with the physiological fluids. Corrosion products may cause not only local reactions but also systemic reactions that could affect the body's immune system. For this reason, it is imperative to know the corrosion behavior of these metal alloys in Ringer solution.

Table 1 Composition of the used nickel-based alloys

\begin{tabular}{lccccccccc}
\hline \multirow{2}{*}{ SPECIMENS } & \multicolumn{1}{c}{$\mathrm{Ni}$} & $\mathrm{Cr}$ & $\mathrm{Mo}$ & $\mathrm{Fe}$ & $\mathrm{Nb}$ & $\mathrm{Si}$ & $\mathrm{Cu}$ & $\mathrm{Mn}$ & $\mathrm{Al}$ \\
\hline $\mathbf{1}$ & 60.1 & 24.3 & 10.1 & 2.1 & 1 & - & - & 2 & - \\
$\mathbf{2}$ & 60.8 & 23.9 & 8.8 & 2.4 & 3.8 & - & - & - & - \\
$\mathbf{3}$ & 63.4 & 23.2 & 3 & 9 & - & 1 & - & - & - \\
$\mathbf{4}$ & 72.1 & 20 & - & 7.5 & - & - & - & - & - \\
5 & 64.9 & 17.9 & - & - & - & 1.8 & 9.9 & 3.6 & 1.5 \\
6 & 53.4 & 14.4 & - & - & - & 1.5 & 9.5 & 19.4 & 1.6 \\
\hline
\end{tabular}

Figure 1 OCP variation with time

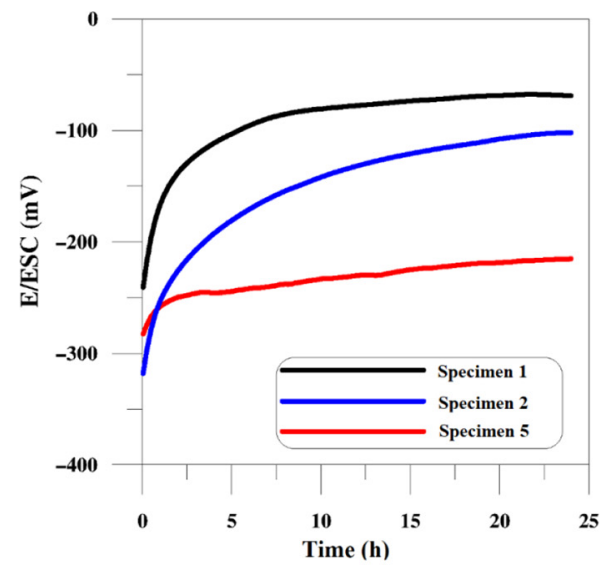

(a)

\section{Materials and methods}

Six commercial Ni-Cr alloys used in dental medicine were studied: three manufactured in Germany, two in Romania and one in the USA. The dental materials will be hereinafter referred to as specimens $1-6$. Their composition can be found in the Table 1 .

The specimens were received in the form of cylindrical ingots, with a diameter of $11.2 \mathrm{~mm}$ and a height between 1.2 and $2.5 \mathrm{~cm}$, depending on the brand. Specimens were cut along a plane at right angles to the axis of the cylinders, to get five samples of each brand with a cylindrical shape of $2 \mathrm{~mm}$ height and were then embedded into epoxy resin disks. Deionized water was used to ultrasonically clean, after grinding with 320 to 2,500 grit silicon carbide ( $\mathrm{SiC}$ ) abrasive papers and polishing with $1 \mu \mathrm{m}$ suspension of alumina for a smooth reflective finish, techniques used to prepare the test specimens.

The Ringer solution had the following composition: $\mathrm{NaCl}$ $(6.8 \mathrm{~g} / \mathrm{L}), \mathrm{KCl}(0.4 \mathrm{~g} / \mathrm{L}), \mathrm{CaCl}_{2}(0.2 \mathrm{~g} / \mathrm{L}), \mathrm{NaCO}_{3} \mathrm{H}(1 \mathrm{~g} / \mathrm{L})$, glucose $(1 \mathrm{~g} / \mathrm{L}), \mathrm{MgSO}_{4} \cdot 7 \mathrm{H}_{2} \mathrm{O}(0.2 \mathrm{~g} / \mathrm{L})$ and $\mathrm{NaH}_{2} \mathrm{PO}_{4} \cdot \mathrm{H}_{2} \mathrm{O}$ $(0.14 \mathrm{~g} / \mathrm{L})$.

Using a Pt-grid as auxiliary or counter electrode in a conventional electrochemical cell of three electrodes, electrochemical measurements were performed. As reference electrode, the saturated calomel electrode (SCE) was used. Connected to a computer with a lock-in amplifier PAR 5210 (Princeton Applied Research, USA), a PAR model 263 A potentiostat was used, using PAR software Electrochemistry Power Suite. The measurements complied with the test procedures and methods provided by the ISO standard for Dentistry, to analyze the corrosion behavior in the oral environment of metallic materials (ISO 10271:2020, DentistryCorrosion test methods for metallic materials).

OCP measurements during $24 \mathrm{~h}$ were performed, followed by linear potentiodynamic polarization measurements, using a $0.5 \mathrm{mV} /$ $\mathrm{s}$ scanning rate, stepping the potential from $-600 \mathrm{mV}$ to $+1200 \mathrm{mV}$ (SCE). The PowerCorr software was used to collect and process the experimental data.

Linear potentiodynamic polarization studies were conducted to identify the Tafel slopes $\left(b_{A}\right.$ and $\left.b_{C}\right)$ for the partial anodic

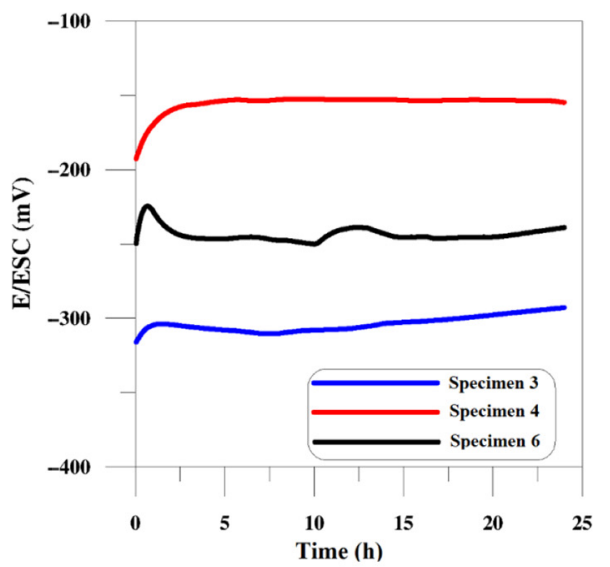

(b)

Notes: (a) specimens 1, 2 and 5; (b) specimens 3, 4 and 6 
and cathodic processes, using a $0.25 \mathrm{mV} / \mathrm{s}$ scanning rate, from $\mathrm{E}_{\mathrm{OCP}}-150 \mathrm{mV}$ to $\mathrm{E}_{\mathrm{OCP}}+150 \mathrm{mV}$. The passivation process was evaluated from $-600 \mathrm{mV}$ to $+1200 \mathrm{mV}$ (SCE), at a scan rate of $0.5 \mathrm{mV} / \mathrm{s}$. The potentiostat used for the tests was from

Table 2 OCP measurements: initial, after $1 \mathrm{~h}$ and $24 \mathrm{~h}$ for $\mathrm{Ni}-\mathrm{Cr}$ alloys immersed in ringer solution

\begin{tabular}{lccc}
\hline Alloys & Initial & $\begin{array}{c}\text { OCP, mV/ESC } \\
\text { After } \mathbf{~ h}\end{array}$ & After $\mathbf{1}$ day (24 h) \\
\hline $\mathbf{1}$ & -237 & -170 & -73 \\
$\mathbf{2}$ & -314 & -241 & -106 \\
$\mathbf{3}$ & -322 & -311 & -288 \\
$\mathbf{4}$ & -190 & -173 & -152 \\
$\mathbf{5}$ & -279 & -263 & -209 \\
6 & -247 & -232 & -244 \\
\hline
\end{tabular}

Figure 2 Polarization curves

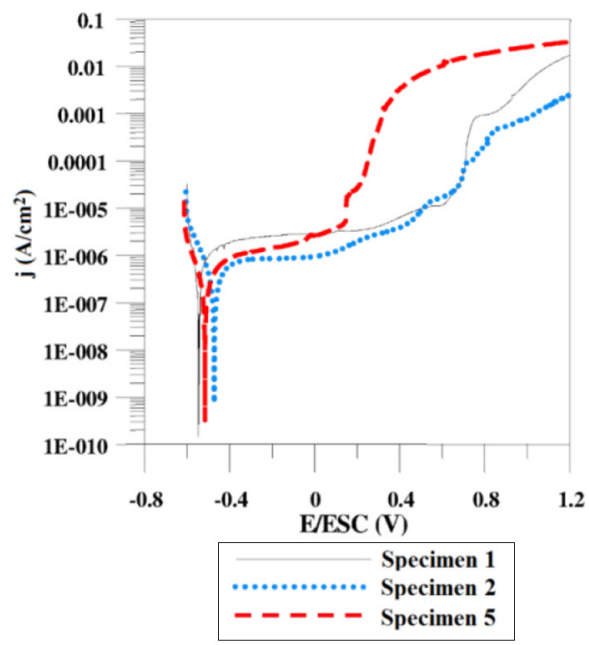

(a)

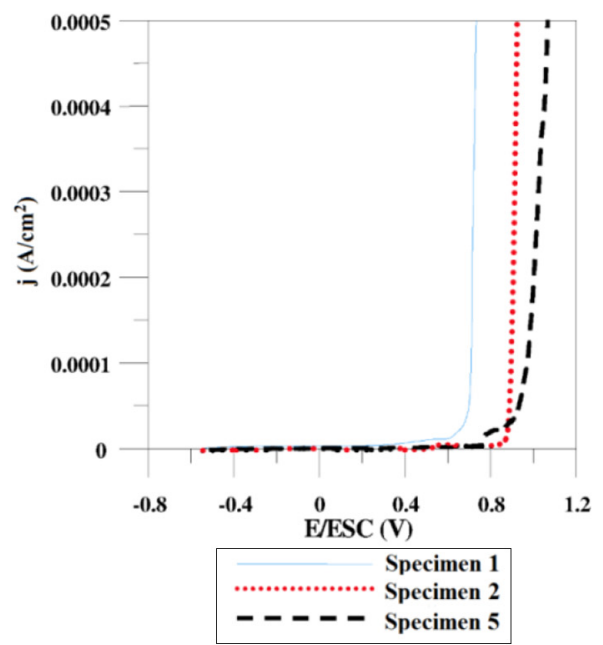

(c)
Princeton Applied Research, as well as the PowerCorr software used to process the data. The potentiodynamic polarization curves and breakdown potential were also obtained from the experimental information.

The alternating current impedance spectra for the six alloys were carried out at the OCP in the aerated solution. The spectra were recorded in the $10^{-2} \mathrm{~Hz}$ to $10^{5} \mathrm{~Hz}$ frequency range, with an amplitude of $10 \mathrm{mV}$.

The EIS tests were performed after $24 \mathrm{~h}$ of immersion at the OCP to examine the corrosion resistance of the alloys studied.

The results were analyzed using ZSimp Win (PAR software), and the relevant equivalent circuit was obtained, having the simulated responses and measured data well-fitted. Impedance data was displayed as Nyquist plot, Bode $|Z|$ and Bode phase diagrams, following each experiment. The tests were performed three times.

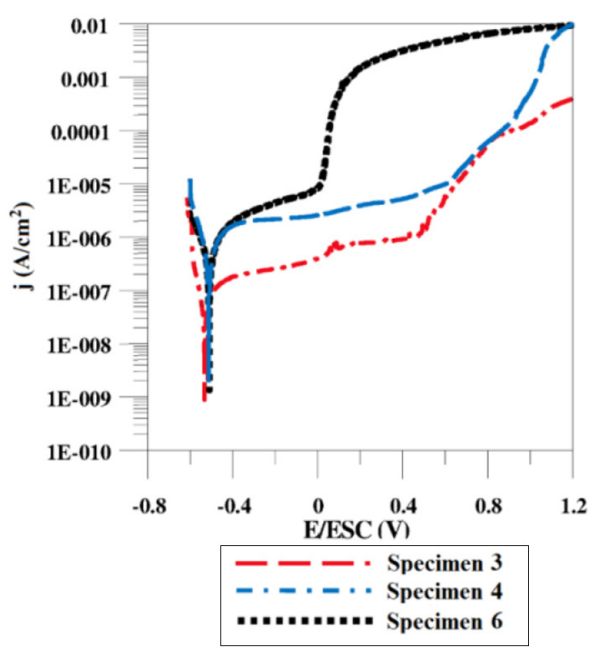

(b)

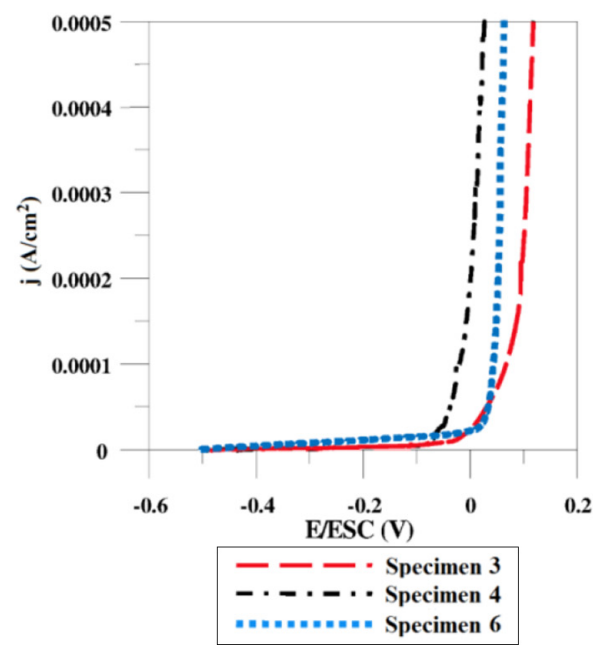

(d)

Notes: (a) specimens 1, 2 and 5; (b) specimens 3,4 and 6; potentiodynamic anodic polarization curves: (c) specimens 1,2 and 5; (d) specimens 3,4 and 6. After one-day immersion in Ringer solution 
Table 3 Electrochemical parameters of the dental alloys at different immersion times in ringer solution

\begin{tabular}{|c|c|c|c|c|c|c|c|}
\hline Specimens & & $\begin{array}{c}\mathrm{i}_{\text {corr }} \\
\mu \mathrm{A} / \mathrm{cm}^{2}\end{array}$ & $\begin{array}{c}\mathbf{R}_{\mathbf{p}} \\
\Omega \mathrm{cm}^{2}\end{array}$ & $\begin{array}{c}b_{A} \\
m V / D I V\end{array}$ & $\begin{array}{c}b_{c} \\
m V / D I V\end{array}$ & $\begin{array}{c}\mathrm{i}_{\text {pass }} \\
\mu \mathrm{A} / \mathrm{cm}^{2}\end{array}$ & $\begin{array}{l}E_{b d} \\
m V\end{array}$ \\
\hline \multirow[t]{3}{*}{1} & After $1 \mathrm{~min}$ & 0.23 & $9.210^{4}$ & 188 & 68 & 4.21 & 500 \\
\hline & After $1 \mathrm{~h}$ & 0.21 & $1.110^{5}$ & 174 & 72 & 3.18 & 500 \\
\hline & After 1 day & 0.20 & $1.210^{5}$ & 157 & 88 & 4.14 & 620 \\
\hline \multirow[t]{3}{*}{2} & After 1 min & 0.21 & $9.210^{4}$ & 128 & 66 & 2.4 & 720 \\
\hline & After $1 \mathrm{~h}$ & 0.17 & $1.110^{5}$ & 116 & 68 & 1.3 & 680 \\
\hline & After 1 day & 0.13 & $1.510^{5}$ & 118 & 70 & 3.5 & 820 \\
\hline \multirow[t]{3}{*}{3} & After $1 \mathrm{~min}$ & 0.78 & $2.810^{4}$ & 140 & 79 & 10.23 & 620 \\
\hline & After $1 \mathrm{~h}$ & 0.66 & $3.910^{4}$ & 150 & 97 & 12.1 & 480 \\
\hline & After 1 day & 0.58 & $4.210^{4}$ & 163 & 85 & 4.66 & 680 \\
\hline \multirow[t]{3}{*}{4} & After $1 \mathrm{~min}$ & 0.65 & $2.910^{4}$ & 129 & 66 & 5.62 & 650 \\
\hline & After $1 \mathrm{~h}$ & 0.39 & $3.910^{4}$ & 124 & 131 & 3.98 & 410 \\
\hline & After 1 day & 0.30 & $8.210^{5}$ & 136 & 95 & 2.58 & 570 \\
\hline \multirow[t]{3}{*}{5} & After 1 min & 0.76 & $3.310^{4}$ & 178 & 85 & 4.60 & 160 \\
\hline & After $1 \mathrm{~h}$ & 0.43 & $7.110^{4}$ & 175 & 117 & 3.48 & 160 \\
\hline & After 1 day & 0.25 & $9.110^{4}$ & 170 & 74 & 4.79 & 160 \\
\hline \multirow[t]{3}{*}{6} & After $1 \mathrm{~min}$ & 0.92 & $1.510^{4}$ & 174 & 39 & 8.3 & 70 \\
\hline & After $1 \mathrm{~h}$ & 0.90 & $1.910^{4}$ & 156 & 54 & 8.6 & 130 \\
\hline & After 1 day & 0.63 & $2.510^{4}$ & 162 & 47 & 10.1 & 40 \\
\hline
\end{tabular}

Table 4 Corrosion indicators. Comparison of $\mathrm{Ni}-\mathrm{Cr}$ dental materials after one week of immersion in simulated body fluid (SBF)

\begin{tabular}{lccc}
\hline Alloys & $\mathrm{i}_{\text {corr }} \mu \mathrm{A} / \mathrm{cm}^{2}$ & $\begin{array}{c}\mathbf{R}_{\mathbf{p}} \\
\Omega \mathrm{cm}^{2}\end{array}$ & $\begin{array}{c}\mathrm{E}_{\mathbf{b d}} \\
\mathbf{m V}\end{array}$ \\
\hline $\mathbf{1}$ & 0.15 & $1.810^{5}$ & 780 \\
$\mathbf{2}$ & 0.11 & $1.610^{5}$ & 820 \\
$\mathbf{3}$ & 0.22 & $6.610^{4}$ & 680 \\
$\mathbf{5}$ & 0.20 & $1.310^{5}$ & 570 \\
$\mathbf{6}$ & 0.21 & $1.410^{5}$ & 180 \\
\hline
\end{tabular}

\section{Results}

The different specimens in this investigation were divided into two groups according to the greater similarity of the analyzed properties. This categorization was useful for the comprehensive interpretation of the graphs and the full analysis of the results.

\subsection{Open circuit potential}

Figure 1 shows OCP measurements after one day of immersion. The curves represent the potentials vs time of the six specimens.

The OCP values for the different alloys studied are summarized in Table 2.

After 1-h immersion, all test specimens had approximately a corrosion potential between $-150 \mathrm{mV}$ and $-350 \mathrm{mV}$. Therefore, in all the dental materials studied, after $1 \mathrm{~h}$ of immersion, there was no passive layer deterioration.

The corrosion potential for Specimens 1, 2, 4 and 5 steadily increased over time to $-73 \mathrm{mV},-106 \mathrm{mV},-152 \mathrm{mV}$ and $-209 \mathrm{mV}$, respectively. In the case of specimen 3, it was found that after $4 \mathrm{~h}$ of immersion, the corrosion potential began to decrease. However, this decline was followed by a new growth, a repassivation, so the passive layer recovered over time, and after $24 \mathrm{~h}$, the corrosion potential stabilized in a fairly negative value of $-288 \mathrm{mV}$. Specimen 6 had continuous patches and repairs of the passive layer. The variation curve of the corrosion potential showed two downward slopes followed by increases. Overall, results showed that after 24-h immersion in Ringer solution, the corrosion potential of specimen 6 changed within a fairly narrow range.

\subsection{Potentiodynamic polarization results}

The curves obtained for the six alloys studied are displayed in Figure 2.

The values of the electrochemical parameters at different immersion times in Ringer solution were determined with the PowerCorr program (see Table 3 ): $\mathrm{R}_{\mathrm{p}}$ (polarization resistance), $b_{A}$ and $b_{C}$ (Tafel slope for anodic and cathodic process), $i_{\text {corr }}$ (corrosion current density), $i_{\text {pass }}$ (passive current density) and $\mathrm{E}_{\mathrm{bd}}$ (breakdown potential).

However, for the purpose of this investigation, the most important indicators of the corrosion process obtained after one week of immersion are presented in a separate table (Table 4 ).

Results in Table 4 showed that specimens 1 and 2 (both with a high concentration of Mo) exhibited lower values of $i_{\text {corr }}$ and higher $\mathrm{R}_{\mathrm{p}}$ and $\mathrm{E}_{\mathrm{bd}}$ in comparison to the other test specimens, with a lower Mo bulk content.

\subsection{Electrochemical impedance spectroscopy}

Representative EIS data of the six alloys in Ringer solution, after one day of immersion, are displayed in Figure 3. Experimental measurements are represented by individual points and the theoretical spectra obtained from the fits to the equivalent circuit (EC) model by lines.

In all the specimens studied, the Nyquist diagram showed a capacitive arc. The Bode $|\mathrm{Z}|$ spectra obtained indicated that in the higher frequency region, with increasing frequency, phase angle values approached 0 degrees and $\log |Z|$ exhibited a tendency to be constant. In the examination of the impedance 
Figure 3 Representative Nyquist and Bode spectra after one day of immersion in Ringer solution
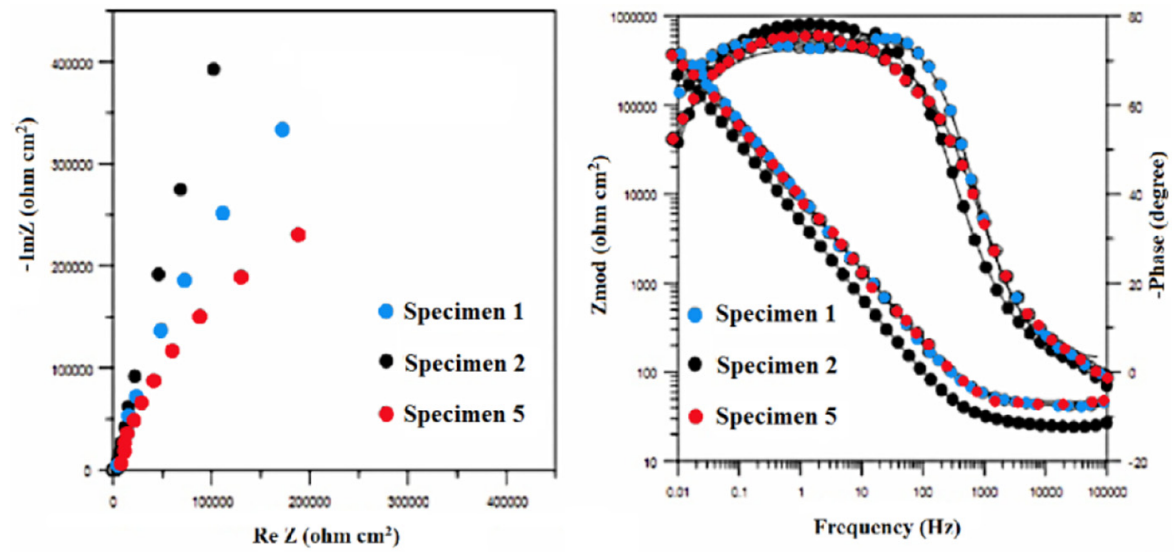

(a)
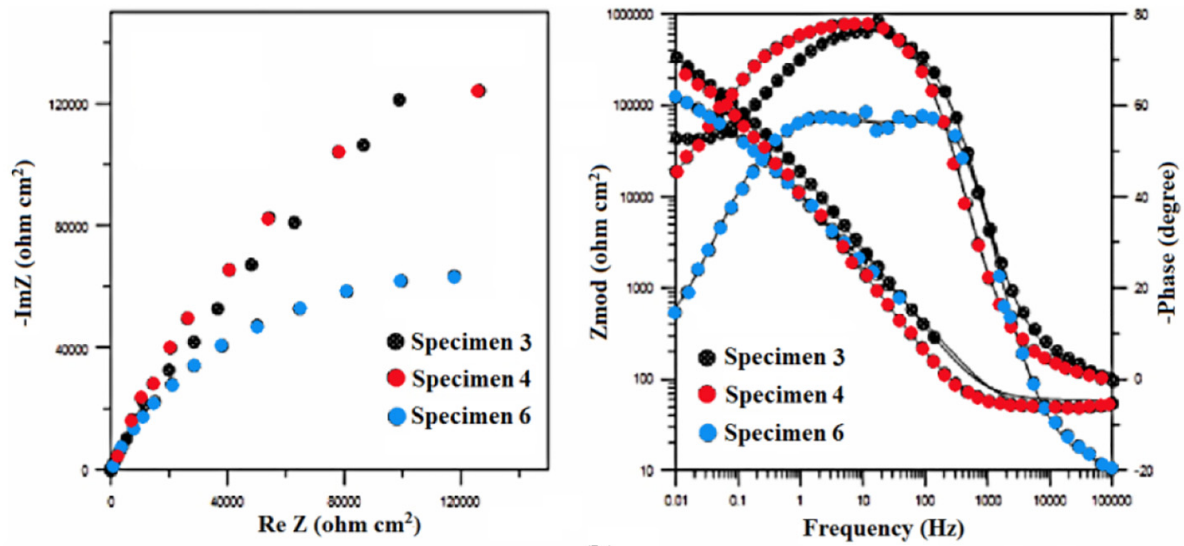

(b)

Notes: (a) specimens 1,2 and 5; (b) specimens 3, 4 and 6

Figure 4 EC used in the experimental data fitting

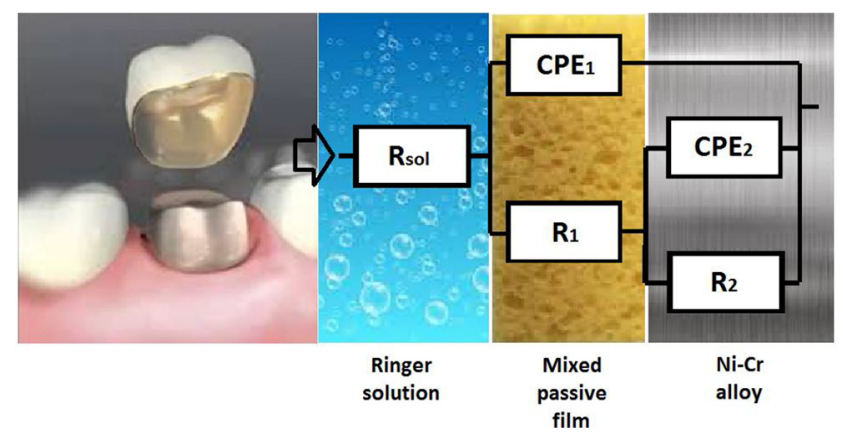

spectra obtained, and after various models were tested starting with the simplest one (Turdean et al., 2019; Qian et al., 2016), it was found that all determinations could be adequately fitted with the equivalent circuit (EC) given in Figure 4. The resulting parameters are provided in Table 5.

In the model, the ohmic resistance of the electrolyte was represented $R_{\text {sol, }}$, the charge transfer resistance $\left(R_{c t}\right)$ was represented as $R_{2}$, the resistance of the passive film was designated $R_{1}$, the passive film capacitance was designated $\mathrm{CPE}_{1}$ and the double layer capacitance $\mathrm{CPE}_{2}$. The EC model shows similarity to that proposed by other authors for cobaltchromium alloys immersed in simulated physiological solution (Metikoš-Huković et al., 2006) and for nickel-chromiummolybdenum alloys in artificial saliva (Moslehifard et al., 2019).

\section{Discussion}

All the Ni-Cr dental alloys, after 1-h of immersion, presented an increase in the corrosion potential because of the formation of passive layers on the surface. An anodic control of the process of corrosion, which suggested the existence of a passive film on the surface of the materials, was indicated by the higher value of $b_{A}$ vs $b_{C}$ in the six specimens (Table 3 ).

The comparison of the corrosion data obtained revealed that the six specimens changed, from the Tafel region, into a passive stable behavior, not showing an active-passive traditional transition (Table 4). This was due to the chromium content, which was reported to be passive at the anode polarization (Qiu et al., 2011). Additionally, specimens 1, 2 and 3 containing molybdenum had smaller corrosion current densities that decreased with the increase of Mo content. 
Table 5 Fitted EIS parameters of the Ni-Cr dental materials after one day of immersion in Ringer solution

\begin{tabular}{|c|c|c|c|c|c|c|c|c|}
\hline Specimens & $\begin{array}{c}\mathbf{R}_{\mathrm{sol}} \\
\Omega \mathrm{cm}^{2}\end{array}$ & $\begin{array}{c}\mathbf{R}_{1} \\
\Omega \mathrm{cm}^{2}\end{array}$ & $\begin{array}{c}\mathrm{CPE}_{1} \\
\mathrm{~S} \mathrm{~cm}^{-2} \mathrm{~s}^{\mathrm{n}}\end{array}$ & $\mathrm{n}_{1}$ & $\begin{array}{c}\mathbf{R}_{2} \\
\mathrm{k} \Omega \mathrm{cm}^{2}\end{array}$ & $\begin{array}{c}\mathrm{CPE}_{2} \\
\mathrm{~S} \mathrm{~cm}^{-2} \mathrm{~s}^{\mathrm{n}}\end{array}$ & $\mathrm{n}_{2}$ & $\chi^{2}$ \\
\hline$\overline{1}$ & 28 & $1.810^{4}$ & $2.010^{-5}$ & 0.87 & 350 & $6.710^{-6}$ & 0.82 & $310^{-4}$ \\
\hline 2 & 39 & $1.310^{3}$ & $1.910^{-5}$ & 0.9 & 460 & $210^{-5}$ & 0.85 & $310^{-4}$ \\
\hline 3 & 56 & $8.810^{4}$ & $1.210^{-5}$ & 0.87 & 500 & $1.010^{-5}$ & 0.8 & $310^{-4}$ \\
\hline 4 & 39 & $10^{4}$ & $1.810^{-5}$ & 0.87 & 430 & $1.310^{-5}$ & 0.78 & $910^{-4}$ \\
\hline 5 & 42 & $610^{4}$ & $1.410^{-5}$ & 0.9 & 400 & $2.410^{-5}$ & 0.81 & $310^{-4}$ \\
\hline 6 & 57 & $1.210^{3}$ & $0.710^{-5}$ & 0.87 & 200 & $1.810^{-5}$ & 0.63 & $610^{-4}$ \\
\hline
\end{tabular}

Based on the chemical composition, the pitting resistance equivalent number (PREN) index is a measurement that predicts a material's resistance to pitting corrosion. This investigation analyzed the PREN-value and the results obtained in the investigation to draw conclusions. The greater PREN value meant the material was more resistant to localized pitting corrosion (Tian et al., 2019). The index was calculated with the mathematical expression:

$$
\text { PREN index }=w t \% \mathrm{Cr}+3.3(\mathrm{wt} \% \mathrm{Mo})
$$

For the dental alloys studied, the PREN values are presented in Table 6.

A PREN value higher than 38 provides an increased resistance to pitting corrosion. Therefore, only specimens 1 and 2 were pitting corrosion resistant.

According to the polarization curves in the 300 to $600 \mathrm{mV}$ anodic area, specimens 1, 2, 3 and 4 displayed the best behavior with anodic currents in the order of $\mu \mathrm{A}$. Specimens 5 and 6 exhibited the worst behavior in the mentioned area, with anodic currents in the order of $\mathrm{mA}$, because of $\mathrm{Al}$ content.

From the analysis of the impedance spectra obtained, different results were found for the two groups of alloys: specimens 1, 2 and 5; specimens 3, 4 and 6. The Bode phase spectra for the first group exhibited, at low and medium frequencies, phase angles close to $90^{\circ}$, indicating the development of a compact passive layer on their surface. The second group did not exhibit high phase angles in the low and medium frequency range, indicating that the passive film formed on these alloys was defective in nature.

In Table 5, specimen 1 with an important concentration in $\mathrm{Cr}$ and the highest concentration on Mo showed the best corrosion behavior. Chromium formed a passive and resistant $\mathrm{Cr}_{2} \mathrm{O}_{3}$ pellicle and molybdenum a $\left(\mathrm{Mo}_{7} \mathrm{O}_{24}\right)^{6-}$ polymolybdate compound that had low solubility and slowed down the pitting corrosion. It was found that the addition of $\mathrm{Nb}$ was also beneficial for the corrosion behavior, because it formed oxides $\left(\mathrm{NbO}\right.$ and $\left.\mathrm{Nb}_{2} \mathrm{O}_{5}\right)$ in the passive film.

Table 6 PREN values of the six $\mathrm{Ni}-\mathrm{Cr}$ alloys

\begin{tabular}{lc}
\hline Specimens & PREN \\
\hline 1 & 57.6 \\
2 & 52.9 \\
3 & 33.1 \\
4 & 20.0 \\
5 & 17.9 \\
6 & 14.4 \\
\hline
\end{tabular}

The sum of $R_{1}$ and $R_{2}$ is the polarization resistance $\left(R_{p}\right)$ of the dental materials in Ringer solution. This value represents the level of resistance of the passive films formed on their surfaces. According to ASM International Handbook (Vander, 2004), Rp can reach values of $1 \mathrm{M} \Omega \cdot \mathrm{cm} 2$ in those materials with high resistance to corrosion. For all the determinations, $R_{p}$ is high (more than $10^{5} \Omega \cdot \mathrm{cm}^{2}$ ), indicating the great stability of the specimens in Ringer solution. Therefore, findings in this investigation revealed that the passive films formed on the surfaces of the six Ni-Cr alloys examined in Ringer solution had a satisfactory resistance to corrosion.

\section{Conclusions}

The following items were concluded in this investigation:

- The dental materials examined were under the influence of an anodic control, due to the formation of protective layers, most likely of oxide, on their surfaces.

- When the materials were compared, it was discovered that the decisive factor for high corrosion resistance was the chromium content. Findings showed that specimens 1 and 2 exhibited a similar behavior at the same concentration, approximately $24 \% \mathrm{Cr}$.

- In terms of predisposition to corrosion, although the chromium concentration was similar for specimens 2 and 3, specimen 2 presented a higher corrosion resistance attributable to the stronger concentration in molybdenum, because of the low solubility of its products in Ringer solution, which inhibited pitting corrosion.

- Findings in this investigation showed that the alloys studied had an adequate corrosion resistance in Ringer solution. However, this study revealed specimens 1 and 2 presented an increased corrosion resistance in Ringer solution and displayed higher polarization resistance values $\left(R_{p}\right)$.

- According to the results obtained, the biological safety of the six Ni-Cr dental materials examined in Ringer solution was considered very high for specimens 1 and 2 and adequate for the other samples.

\section{References}

Alp, G., Çakmak, G., Sert, M. and Burgaz, Y. (2018), "Corrosion potential in artificial saliva and possible genotoxic and cytotoxic damage in buccal epithelial cells of patients who underwent $\mathrm{Ni}-\mathrm{Cr}$ based porcelain-fused-to-metal fixed 
dental prostheses", Mutation Research/Genetic Toxicology and Environmental Mutagenesis, Vol. 827, pp. 19-26.

Craig, R.G. and Hanks, C.T. (1988), "Reaction of fibroblasts to various dental casting alloys", Fournal of Oral Pathology and Medicine, Vol. 17 No. 7, pp. 341-347.

Craig, R.G. and Hanks, C.T. (1990), "Cytotoxicity of experimental casting alloys evaluated by cell culture tests", Fournal of Dental Research, Vol. 69 No. 8, pp. 1539-1542.

Eliaz, N. (2019), "Corrosion of metallic biomaterials: a review”, Materials, Vol. 12 No. 3, p. 407.

Garcia-Falcon, C.M., Gil-Lopez, T., Verdu-Vazquez, A. and Mirza-Rosca, J.C. (2021), "Electrochemical characterization of some cobalt base alloys in ringer solution", Materials Chemistry and Physics, Vol. 260, p. 124164.

Gushcha, D., Parii, V., Tyshko, D., Mykhailov, A. and Shpak, D. (2019), "The study of Ni-Cr, Co-Cr dental alloys and ceramics chemical indifference using $\mathrm{ZrO} 2-\mathrm{HfO} 2-\mathrm{Y} 2 \mathrm{O} 3$ system in vitro", Research Fournal of Pharmacy and Technology: RfPT, Vol. 12 No. 9, pp. 4085-4089.

Honga, M.H., Hanawa, T., Song, S.H., Min, B.K. and Kwon, T.Y. (2019), "Enhanced biocompatibility of a Ni-Cr alloy prepared by selective laser melting: a preliminary in vitro study", fournal of Materials Research and Technology, Vol. 8 No. 1, pp. 1587-1592.

Hornez, J.C., Lefèvre, A., Joly, D. and Hildebrand, H.F. (2002), "Multiple parameter cytotoxicity index on dental alloys and pure metals", Biomolecular Engineering, Vol. 19 Nos 2/6, pp. 103-117.

Insel, P., Ross, D., McMahon, K. and Bernstein, M. (2018), Nutrition, 6th ed., Jones \& Bartlett Learning, MA.

Lee, J.H., Yi, S.J., Seol, H.J., Kwon, Y.H., Lee, J.B. and Kim, H.I. (2006), "Age-hardening by metastable phases in an experimental Au-Ag-Cu-Pd alloy", Foumal of Alloys and Compounds, Vol. 425 Nos 1/2, pp. 210-215.

López-Alías, J.F., Martinez-Gomis, J., Anglada, J.M. and Peraire, M. (2006), "Ion release from dental casting alloys as assessed by a continuous flow system: nutritional and toxicological implications”, Dent. Mater., Vol. 22 No. 9, pp. 832-837.

McGinley, E.L., Moran, G.P. and Fleming, G.J.P. (2013), "Biocompatibility effects of indirect exposure of base-metal dental casting alloys to a human-derived three-dimensional oral mucosal model", Fournal of Dentistry, Vol. 41 No. 11, pp. 1091-1100.

Mareci, D., Cailean, A., Ciurescu, G. and Sutiman, D. (2010), "Electrochemical determination of the corrosion resistance of NiCr dental casting alloys", The Open Corrosion fournal, Vol. 3 No. 1, pp. 45-53.

Mareci, D., Sutiman, D., Cailean, A. and Bolat, G. (2010), "Comparative corrosion study of Ag-Pd and $\mathrm{Co}-\mathrm{Cr}$ alloys used in dental applications", Bulletin of Materials Science, Vol. 33 No. 4, pp. 491-500.

Mareci, D., Sutiman, D., Cretescu, I., Cailean, A. and Mirza Rosca, J.C. (2008), "Electrochemical characterization of some copper based dental materials in accelerated test solutions", Revista de Chimie, Vol. 59 No. 8, pp. 871-877.

Mareci, D., Ungureanu, G., Aelenei, N., Chelariu, R. and Mirza-Rosca, J.C. (2007), "EIS diagnosis of some dental alloys in artificial saliva”, Environmental Engineering and Management fournal, Vol. 6 No. 4, pp. 313-317.

Mareci, D., Ungureanu, G., Aelenei, N. and Mirza-Rosca, J.C. (2008), "Comparative corrosion study of non-precious Ni/Crbased soft alloys in view of dental applications", Environmental Engineering and Management fournal, Vol. 7 No. 1, pp. 41-49.

Metikoš-Huković, M., Pilić, Z., Babić, R. and Omanović, D. (2006), "Influence of alloying elements on the corrosion stability of CoCrMo implant alloy in hank"s solution", Acta Biomaterialia, Vol. 2 No. 6, pp. 693-700.

Moslehifard, E., Ghasemzadeh, S. and Nasirpouri, F. (2019), "Influence of $\mathrm{pH}$ level of artificial saliva on corrosion behavior and nickel ion release of a Ni-Cr-Mo alloy: an in vitro study", Anti-Corrosion Methods and Materials, Vol. 66 No. 6, pp. 746-756.

Qian, C., Wu, X., Zhang, F. and Yu, W. (2016), "Electrochemical impedance investigation of Ni-free Co-Cr$\mathrm{Mo}$ and Co-Cr-Mo-Ni dental casting alloy for partial removable dental prosthesis frameworks", The fournal of Prosthetic Dentistry, Vol. 116 No. 1, pp. 112-118.

Qiu, J., Yu, W.Q., Zhang, F.Q., Smales, R.J., Zhang, Y.L. and Lu, C.H. (2011), "Corrosion behaviour and surface analysis of a $\mathrm{Co}-\mathrm{Cr}$ and two Ni-Cr dental alloys before and after simulated porcelain firing", European Fournal of Oral Sciences, Vol. 119 No. 1, pp. 93-101.

Rupp, F., Liang, L., Geis-Gerstorfer, J., Scheideler, L. and Hüttig, F. (2018), "Surface characteristics of dental implants”, Dental Materials, Vol. 34 No. 1, pp. 40-57.

Souza, M.A.d., Fiorin, B.d.O., Hashimoto, T.M., Rosifini, A. P., Nunes, C.A., Baptista, C.A.R.P. and Ramos, A.S. (2019), "Influence of niobium or molybdenum addition on microstructure and tensile properties of nickel-chromium alloys", Metals, Vol. 9 No. 5, p. 589.

Taher, N.M. and Al Jabab, A.S. (2003), "Galvanic corrosion behavior of implant suprastructure dental alloys", Dental Materials, Vol. 19 No. 1, pp. 54-59.

Tian, K.V., Passaretti, F., Nespoli, A., Placidi, E., Condò, R., Andreani, C., Licoccia, S., Chass, G.A., Senesi, R. and Cozza, P. (2019), "Composition-nanostructure steered performance predictions in steel wires", Nanomaterials, Vol. 9 No. 8, p. 1119.

Turdean, G.L., Craciun, A., Popa, D. and Constantiniuc, M. (2019), "Study of electrochemical corrosion of biocompatible $\mathrm{Co}-\mathrm{Cr}$ and $\mathrm{Ni}-\mathrm{Cr}$ dental alloys in artificial saliva. Influence of $\mathrm{pH}$ of the solution", Materials Chemistry and Physics, Vol. 233, pp. 390-398.

Vander, G.F. (2004), ASM Handbook Volume 9: Metallography and Microstructures, ASM International, $\mathrm{OH}$.

\section{Corresponding author}

Tomas Gil-Lopez can be contacted at: tomas.gill@upm.es 